\title{
Effect of Organic Manure on Growth of Linseed (Linum usitatissimum L.) Under Poplar Tree Based Agroforestry System
}

\author{
Gyan Shri Kaushal*, Rajiv Umrao
}

Department of Silviculture and Agroforestry, Sam Higginbottom University of Agriculture, Technology and Sciences, Allahabad, India

Email address:

Gyanshri7@gmail.com (G. S. Kaushal)

${ }^{*}$ Corresponding author

\section{To cite this article:}

Gyan Shri Kaushal, Rajiv Umrao. Effect of Organic Manure on Growth of Linseed (Linum usitatissimum L.) Under Poplar Tree Based Agroforestry System. Journal of Plant Sciences. Vol. 8, No. 5, 2020, pp. 120-122. doi: 10.11648/j.jps.20200805.13

Received: September 29, 2019; Accepted: November 7, 2019; Published: September 21, 2020

\begin{abstract}
A field experiment was conducted with linseed under Poplar during Rabi season of 2018 at crop Research Farm, Department of Silviculture \& Agroforestry, SHUATS, Prayagraj, (U. P.). An approach to land use that incorporates trees into farming systems, and allows for the production of trees and crops or livestock from the same piece of land in order to obtain economic, ecological, environmental and cultural benefits. Fastgrowing energy plant and trees such as poplar are characterized by short-term growth and weight gain significantly exceeding the average growth of other plant during the growing period. Use of vermicompost for crop growth is in focus in recent researches, but the response to the application of vermicompost had been specific to each plant species and the stage of growth. Such as unbalance continuous application of limited fertilizers both in the amount and type may aggravate the depletion of other important nutrients such as $\mathrm{K}, \mathrm{Mg}, \mathrm{Ca}, \mathrm{S}$ and micro-nutrients not supplied by the chemical fertilizer and may also lead to chemical soil degradation. The treatment comprised of FYM $100 \%$, Control, VC $100 \%$, FYM $50 \%$, VC 50\%, FYM 75\%, VC 75\%, FYM 125\%, VC $125 \%$ under Poplar based Agroforestry. The experiment was laid out in Randomized Block Design (RBD). The result Showed that maximum plant height $(\mathrm{cm})$, plant diameter $\left(\mathrm{cm}^{2}\right)$ recorded at 30, 60, 90 and 120 DAT, capsule per plant, seed per capsule were recorded. The treatment $\left(T_{11}\right)$ with application of (FYM 125\%) showed the significant superiority in giving the maximum plant height $(58.41 \mathrm{~cm}$ at 120 days), plant diameter $\left(4.43 \mathrm{~cm}^{2}\right.$ at 120 days), capsule per plant (48.93 at 120 days), and seed per capsule 9.33. Poplar based Agroforestry system could be rank based on economic performance of linseed also recorded in treatment $\mathrm{T}_{11}$ (FYM 125\%).
\end{abstract}

Keywords: Linseed, Growth Analysis, Poplar, Farm Yard Manure, Vermicompost

\section{Introduction}

The theme of Agroforestry centered on sustainability in terms of economics (productivity and profitability), ecology (environmental and resource conservation) and social issues (food security, health and safety) that make it an unparallel land use system [9].

Linseed (Linum usitatissimum L.) belongs to the order Malpighiales, the family Linaceae, and the tribe Lineae. It is the second most important Rabi oilseed crop and stands next to rapeseed-mustard in area of cultivation and seed production in India. The genus Linumis composed of approximately 230 species but cultivated linseed is the only species of economic importance in the genus and is one of the oldest plants cultivated for fibre and oil [13].

The flaxseed growing is in production of seed for food industry and technical purposes and fibre for textile industry. Other technical use of flax is about possible in the field of paper production [7].

Flaxseed is rich in oil (41\%), protein (20\%), dietary fiber (28\%), contains $7.7 \%$ moisture and $3.3 \%$ ashes. It has a high percentage of essential fatty acids, $75 \%$ polyunsaturated fatty acids, $57 \%$ alpha-linolenic acid, which is an omega- 3 fatty acid, and $16 \%$ linoleic acid, which is an omega- 6 fatty acid [8].

Flaxseed is grown as either oil crop or a fiber crop with fiber linen derived from the stem of fiber varieties and oil from the seed of linseed varieties (Diederichsen et al., 2003; 
Vaisey-Genser et al., 2003).

The world area cultivated with flaxseed is 3016940 ha with an annual average seed yield of $852 \mathrm{~kg} \mathrm{ha}^{-1}$. Canada, India, China, and the USA are the main world producers. Canada and the USA have $93 \%$ of the total exported volume (FAO, 2007). After extraction of fibre from stalk, the woody core of the stem and short fibres are used as raw pulp for making high grade paper. To increase the quality of the paper more than $20 \%$ strong virgin wood fibre must be add to the pulp. This extra strong fiber which is to be adding to the pulp is called as pulp sweeteners. As flax fibres are stronger and longer than any other virgin wood fibre, a small quantity of flax fibre can be use in place of virgin wood fibres. This pulp can be utilized for the manufacture of paper used for currency notes, airmail, parchment paper, good writing paper, cigarette paper and straw boards of all grades of economic value [4].

Fast-growing energy plant and trees such as poplar are characterized by short term growth and weight gain significantly exceeding the average growth of other plant during the growing period [6]. Poplar is highly adaptable to the climate in Korea. It grows rapidly and has been widely utilized in timber production and landscaping. In addition, due to its high carbon absorption capacity, Poplar is the major tree species used in reforestation for the formation of bio-circulation forests in order to replace fossil fuels and secure Certified Emission Reductions [10, 11].

Poplar market price trend, which was lowest during 2003 and recovered back during 2005 and recently touched the maximum of Rs. 12,000/- ton, which has again attracted the attention of farmers. It is important to mention that the profitability of Poplar based Agroforestry is only accountable after the harvesting of poplar trees (5-8 yrs) [3].

Use of soil micro-organisms which can either fix atmospheric nitrogen, solubilize phosphate, synthesis of growth promoting substances or by enhancing the decomposition of plant residues to release vital nutrients and increase humid content of soils, will be environmentally begin approach for nutrient management and ecosystem function [15]. Farm yard manure is a decomposed mixture of cattle dung and urine with straw and litter used as bedding material and residues from the fodder fed to the cattle. The waste material of cattle shed consisting of dung and urine soaked in the refuses of the shade is collected daily and placed in trenches about $6-7 \mathrm{~m}$ long, $1.5-2 \mathrm{~m}$ broad and $1 \mathrm{~m}$ deep. Each trench is filled up to a height of about $0.5 \mathrm{~m}$ above the ground level. The top of the heap is to be made dome shaped and plastered over with cow dung earth slurry. It becomes ready to apply after 3-4 months. It is possible to prepare by this process $7-8.5 \mathrm{~m}^{3}$ of manure. Well rotten farmyard manure contains $0.4-1.5 \% \mathrm{~N}, 0.3-0.9 \% \mathrm{P}_{2} \mathrm{O}_{5}$ and $0.3-1.9 \% \mathrm{~K}_{2} \mathrm{O}$.

\section{Material and Methods}

The field experiment was carried out at College of Forestry Sam Higginbottom University of Agriculture, Technology \& Sciences, Prayagraj U. P. India during Rabi season of 2018-19 experimental field is sandy clay loam. The maximum temperature in summer may reach up to $50^{\circ} \mathrm{C}$ and minimum temperature in winter may fall up to $6^{\circ} \mathrm{C}$. The ten year old plantation of Poplar tree at 9x3 m spacing intercropped. The experiment was laid out in Randomized block design with 3 replications and 12 treatments. The organic manure FYM and Vermicompost. Linseed was shown on 05 Nov 2019 at a rows spacing of $30 \mathrm{~cm}$. The full dose of $\mathrm{N}$ was added at the time of sowing to the crop. The sources of FYM and Vermicompost. Farmyard manure was applied @,20 ton/ha to all the plots uniformly and was incorporated into the soil at the time of land preparation.

\section{Results and Discussion}

Table 1. Effect of different types of organic manure on growth of Linseed under Poplar based Agroforestry system at 120 DAS.

\begin{tabular}{llll}
\hline Treatment & Plant height & Plant diameter & Number of capsules per plant \\
\hline T1 & 57.27 & 3.46 & 26.33 \\
T2 & 55.34 & 3.54 & 40.00 \\
T3 & 54.22 & 3.33 & 24.80 \\
T4 & 58.19 & 4.03 & 35.20 \\
T5 & 57.97 & 3.71 & 40.00 \\
T6 & 56.43 & 3.53 & 39.53 \\
T7 & 4.38 & 28.33 \\
T8 & 58.32 & 3.49 & 31.93 \\
T9 & 57.06 & 3.51 & 27.20 \\
T10 & 55.66 & 3.92 & 43.06 \\
T11 & 55.34 & 4.43 & 48.93 \\
T12 & 58.41 & 3.39 & 41.93 \\
\hline
\end{tabular}

\subsection{Plant Height (cm)}

At 30 DAS, The maximum plant the hight was found in treatment $\mathrm{T}_{11} \mathrm{FYM}$ with $14.32 \mathrm{~cm}$. The minimum plant height was found in treatment $\mathrm{T}_{3} \mathrm{VC}$ with $7.48 \mathrm{~cm}$. The result found was found significant. At 60 DAS, The maximum plant height was found in treatment $T_{11} F Y M$ with $29.00 \mathrm{~cm}$. The minimum plant height was found in treatment $\mathrm{T}_{3} \mathrm{VC}$ 
with $23.00 \mathrm{~cm}$. The result obtained was found significant. At 90 DAS, The maximum plant height was found in treatment $\mathrm{T}_{6}$ FYM with $44.76 \mathrm{~cm}$. The minimum plant height was found in treatment $\mathrm{T}_{8} \mathrm{VC}$ with $38.04 \mathrm{~cm}$. The result obtained was found significant. At 120 DAS, The maximum plant height was found in treatment $\mathrm{T}_{6} \mathrm{FYM}$ with 58.41. The minimum plant height was found in treatment $\mathrm{T}_{8} \mathrm{VC}$ with 54.22. The result obtained was found significant.

\subsection{Plant Diameter $\left(\mathrm{cm}^{2}\right)$ at $120 \mathrm{DAS}$}

At 30 DAS, The maximum Plant diameter was found in treatment $\mathrm{T}_{11}$ FYM with 0.82. The minimum Plant diameter was found in treatment $\mathrm{T}_{3} \mathrm{VC}$ with 0.53 . The result obtained was found significant. At 60 DAS, The maximum Plant diameter was found in treatment $\mathrm{T}_{11} \mathrm{FYM}$ with 1.30. The minimum Plant diameter was found in treatment $\mathrm{T}_{3} \mathrm{VC}$ with 1.08 . The result obtained was found significant. At 90 DAS, The maximum Plant diameter was found in treatment $\mathrm{T}_{11} \mathrm{FYM}$ with 2.94. The minimum Plant diameter was found in treatment $\mathrm{T}_{3} \mathrm{VC}$ with 2.01. The result obtained was found significant. At 120 DAS, The maximum Plant diameter was found in treatment $T_{11}$ FYM with 4.43. The minimum Plant diameter was found in treatment $\mathrm{T}_{3} \mathrm{VC}$ with 3.33 . The result obtained was found significant.

\subsection{Capsule Per Plant}

At 120 DAS, The maximum capsule per plant was found in treatment $\mathrm{T}_{11} \mathrm{FYM}$ with 26.20. The minimum capsule per plant was found in treatment $\mathrm{T}_{3} \mathrm{VC}$ with 13.40 . The result obtained was found significant.

\subsection{Seed Per Capsule}

At 120 DAS, The maximum seed per capsule was found in treatment $\mathrm{T}_{11}$ FYM 9.33 The minimum seed per capsule was found in treatment $\mathrm{T}_{3} 7.06$ (VC 100\% (Control) under Poplar based Agroforestry system respectively. The result obtained was found significant throughout the seed per capsule.

\section{Conclusion}

In view of the findings and results presented above, it is concluded that among all the nine different treatments, the treatment FYM had emerge the best on the growth parameter like plant height, Plant diameter, capsule per plant, seed per capsule. $\mathrm{T}_{11}$ FYM emerged best for the growth attributes of Linseed (Linum usitatissimum) and as well as for Poplar based to Agroforestry system. Trials in Utter Pradesh India, found that Linseed (Linum usitatissimum) could be grown successfully between lines of Poplar tree spaced 3.0 meters apart. The linseed (Linum usitatissimum) was planted in the dry season with limited irrigation, when there was no leaf cover from the Poplar. It was found that this system helped with weed control of the plantation and that the growth of intercropped Poplar was better, however science this is based on one-year experiment, further trails may be needed to substantiate the results.

\section{References}

[1] Anjum Arshiya., Aswathanarayana Dash. S. And Ajithkumar K., (2017). Management of Linseed Powdery Mildew Caused By Leveillula Taurica (Lev.) Arn. International Journal of Agriculture Sciences. (32 (9)), (4479-4481).

[2] Anonymous, (2012). Economic survey of India, Economic Division Ministry of Finance Govt. of India.

[3] Gupta, D. C. Zomer, R. J. and Bossio, D. A. (2005). Poplar agroforestry in India: Trends and impacts. IWMI Project Report. Colombo, International Water Management Institute.

[4] Janakinath Dash., Bhima Sen Naik and Uma Ballav Mohapatra, (2017). Linseed: a valuable crop plant. International Journal of Advanced Research, (5 (3)), (1428-1442).

[5] Kohl L., van der Heijden M G A. (2016). Arbuscular mycorrhizal fungal species differ in their effect on nutrient leaching. Soil Biology and Biochemistry, (191-199).

[6] Kolonicny. J., (2005). Biomass as a source of energy (Biomasa jako zdroj energie). Dostupne na internete: http://www. Biomass-info.cz/cs/doc/zdroj.pdf (in Slovak).

[7] Lebrun, G., Couture, A. And Laperriere, L. (2013). Tensile and Impregnation Behavior of Unidirectional Hemp/paper/epoxy and Flax/paper/epoxy Composites. Composite Structures, (103), (151-60).

[8] Morris, D., (2005). Flax-A health and nutrition Primer. Flax Council of Canada. Available at http://www.flaxcouncil.ca/english/index.phpp=primer\&mp=n utrition.

[9] Pandey, D. N. (2007). Multifunctional agroforestry systems in India. Current Science, (92: 455-463).

[10] RyuKo, Kim Uj, Kim Is, Choi Hs, Lee Dh, Kim Yw., (2008). Liriodendron tulipifera L. growth characteristics and utilization technique. Korea Forest Research Institute; p (320).

[11] RyuKo, Jang SS, Choi Wy, Kim HE., (2003). Growth performance and adaptation of Liriodendron tulipifera in Korea. J Korean For Soc. (92 (6)), (515-525).

[12] Uttam Kumer Sarker., Md. Romij Uddin., Md. Abdur Rahman Sarkar., Md. Abdus Salam Ahmed Garrett, H. E., Rietveld, W. J., Fisher, R. F., Kral, D. M., Viney, M. K. (Eds.), (2000). North American Agroforestry: An Integrated Science and Practices. American Society of Agronomy, Madison, Wisconsin.

[13] Tadesse, T., Parven, A., Singh, H. and Weyessa, B., (2010). Estimates of variability and heritability in linseed germplasm. International Journal of Sustainable Crop Production, (5 (3)), (8-16).

[14] Thevathasan, N. V., Gordon, A. M., Simpson, J. A., Reynolds, P. E., Price, G. W., Zhang, P., (2004). Biophysical and ecological interactions in a temperate tree-based intercropping system. J. Crop Improv., (1-2), (339-363).

[15] Wu, S. C., Cao, Z. H. Li, Z. G. and Cheung, K. C. (2005). Effect of biofertilizer containing $\mathrm{N}$-fixer, $\mathrm{P}$ and $\mathrm{K}$ solubilizers and AM fungi on maize growth: a greenhouse trial. Geoderma. (125), (155-166). 